\title{
Chinese Products in Ivory Coast: A New Material Culture and New Figures of Success
}

\author{
Salomon Mahotogui \\ École des Hautes Études en Sciences Sociales (EHESS), Paris, Frances
}

\begin{abstract}
In this paper, we will focus on consumers of Chinese products, but also other key players in this revolution of Chinese products in Ivory Coast: Ivorian traders, paying particular attention to the micro-social consequences of the arrival of Chinese products on the daily lives of Ivorian people. To date, work on relations between China and Africa is still struggling to grasp the micro-social consequences of Sino-African trade in African economies. Most of this work perceives Sino-African trade in terms of threats or opportunities for the development of African economies. While attention is generally focused on Chinese imports from Africa, given their geostrategic value, we want to show, in the case of Ivory Coast, the profound transformations induced by imports of Chinese products into Ivorian society. Sino-Ivorian trade has grown rapidly in recent years. While in 2012, exports of Ivorian products by China were 55,515 billion francs CFA (Communauté financière d'Afrique); in 2016, they reached $42,383^{1}$ billion francs CFA, On the other hand, imports from China increased by a whopping 364,103 billion francs CFA in 2012, reaching 885,699 billion francs CFA in 2016. This increase in imports of Chinese products by Ivory Coast corresponds to the arrival of a wide variety of manufactured products in the Ivorian market. For many Ivorians, the presence of these products on the Ivorian market is an expression of good Sino-Ivorian cooperation. In order to appreciate the various dimensions of Chinese products in Ivorian territory, our communication will be part of an interdisciplinary approach and will be based on empirical observations and interviews conducted in Ivory Coast during 2014-2016.
\end{abstract}

Keywords: China, Ivory Coast, new success figures, chiois products

\section{Chinese Products in Ivory Coast}

Chinese presences in Ivory Coast are not limited to physical (men) and/or moral actors (companies and institutions). It is also visible by the "Made in China". Thus, the Chinese presences on the territory are not only based on struggles for the control of the natural resources, nor obtaining big contracts. These also contain deep issues of the social transformations that take place in the everyday life of the population in a banal way and very often far from the centers of interest of cooperation between states.

The quantitative and dramatic increase in imports of Chinese products by Ivory Coast shows an equally radical evolution in the variety of imported consumer products as their place in the life of the Ivorian population. Trade between Ivory Coast and China makes technological innovations accessible which appears

Salomon Mahotogui, Ph.D. Candidate, Socioeconomist Independent Researcher, École des Hautes Études en Sciences Sociales (EHESS), Paris, Frances.

${ }^{1}$ Ivorian customs statistics. 
for some people, the only alternative. Generally speaking, Sino-Ivorian exchanges "democratize" access to new ranges of goods, some of which were previously considered as luxury goods. For a better understanding, we have distinguished three types of Chinese products presented on the Ivorian market. First of all, the first group of products is the one we probably talked about the most, since it is taking part of a dynamic of competition with the "old" products of current consumption. Sometimes, derived from local industry or handicrafts, they were also often imported, especially in the West African very little industrialized countries. These are clothes, shoes, loincloths, kitchen utensils, etc.

Then, a second group of products is composed of "old" luxury products. Generally, products imported from Europe whose access was previously limited to a small elite. Here, we talk about vehicles, household appliances (washing machines, refrigerators, etc.), electrical equipment (air conditioning systems, fans, etc.), or electronics (TVs, DVD players, computers, hi-fi systems, and mobile phones). The arrival of these Chinese products largely democratized access to the consumption of these luxury goods markers of social success.

Finally, there are the "new" consumer products, often forgotten by the literature because of their uselessness apparent. These are plastic flowers, paintings, posters, toys, Christmas decorations, or other rather innocuous fashion accessories. These products were almost non-existent in Ivory Coast before being imported from China. They are gradually becoming standard consumer goods.

The presence of three types of products brings about as social consequences, the emergence of a new material culture.

\section{Chinese Products in Ivory Coast: A New Material Culture}

Every day, the district of Adjamé is in full effervescence. Customers flock to the stalls and the many commercial establishments lining the market. A Chinese shop, known for its large selection of shoes, jeans, and T-shirt, is always full. All are engaged in a buying frenzy often leading to the acquisition of pairs of new shoes and pants that they would never dream of having elsewhere. Not far away, a small salesman presents on a wooden board, Chinese mobile phones to customers, having already two laptops for the most part, all "Made in China". These observations, which can be made in any commercial district of Abidjan, testify that the commoditization of the consumption of Chinese products is real.

In Ivory Coast as elsewhere in Africa, Chinese traders adapt themselves to the fashions and seasons of Ivorians. Also have a wide range of choices. Thanks to the knowledge of Chinese companies in copies, local or European products are copied and sold back at half price from those produced by European or local industry. Even if the quality is lower, the prices defy all competition and the consumers love it. Ivorian consumers are well aware of this quality/price ratio. Of course, a pair of pants bought at 1,000 FCFA (Franc de la Communauté financière d'Afrique) will last only a few months at most. However, the Chinese also offer high-end goods for wealthy populations and less sophisticated products for smaller grants. The strategy is to offer to every Ivorian a product "Made in China".

For the surveyed consumers, the use of these products is perceived as an evidence because of their price. Up to 10 times less expensive, they arouse a certain attraction. Far from being fooled by Chinese products, Ivorian consumers make their choice on all products available on the market, adapting their consumption according to contexts and needs. Mr. Koffi Clément ${ }^{2}$ lives in a village in Daloa, a city located at $450 \mathrm{~km}$ from

\footnotetext{
${ }^{2}$ Interview conducted on June 12, 2015 in Daloa.
} 
the capital. Aged about 30, draws his income from the motor tricycle trade.

His activity consists of bringing food products out of plantations, whose tracks are hardly accessible to trucks. It is with enthusiasm that he easily remembers the exact day of his acquisition, six months earlier.

"Thanks to this bike tricycle my life has changed, said our passionate for Chinese products". Koffi explains us: "Chinese three wheeled motorcycle help us to solve our displacement problems, In any case, you can do nothing in our countryside without these motorcycle-tricycles. Already to deal a business in another village you must be mobile. And it gives you money". In addition, he lets us know that he consumes 100 percent Chinese, "from my laptop to my bike through my clothes, it is made in China". To the question of duration of these Chinese products, the answer of our interlocutor is well-known to Africans: "We can not usually repair Chinese products when they fail". The anecdote looks funny and leads to a well-honed chorus: "That's how it's done, but how are we going to manage with it? We have no choice!"’3. In the capital as in the provinces, the ostentatious staging of Chinese products is our everyday life reality.

This profile shows that consumption of Chinese products exceeds too much the scope of financial captivity. The use made by Koffi of his Chinese three-wheeled motorcycle in specific contexts: works, visits to parents, solves a problem, and gives this property an eminently prestigious scope. The ostentatious staging of Chinese products, especially consumer goods, which is particularly visible among young Ivorians reveals the complexity of a consumption where a multitude of logics are entangled.

By visiting the homes of cities and countryside, we are struck by the disruption of consumption habits of Ivorians by Chinese products. For many Ivorians, the arrival of Chinese products has allowed access to consumer goods (motorcycles, computers, air conditioning units, mobile phones, etc) that they could never buy. The case of Chinese motorcycles (The DJAKATA) helps us understand how Chinese products have democratized the access of prestige products in Côte d'Ivoire. Before the arrival of Chinese motorcycles, the cheapest Japanese motorbikes were sold to a million Francs (1,000,000 FCFA) or $1500 €$, today with about 300,000 FCFA, or $450 €$; we buy this machine of Chinese manufacture. Before the arrival of the Chinese motorcycles, the access to the motorbike was reserved for a certain category of people; the motorbike was in fact a product of prestige. Since the arrival of the Chinese, to have a motorbike became a necessity for Ivorian consumer. Chinese motorcycles are one of the most visible signs of products "Made in China" in Ivory Coast.

These goods are often criticized for their negative impact on the process of industrialization of the African continent, or for their role in establishment of unfair competition between Chinese and African traders. As a result, work on the consequences of Sino-African trade often obscures the flexibility with which a majority of African businessmen integrate these goods into the daily management of their activities. The massive importation of cheap Chinese products into Côte d'Ivoire is bringing many opportunities for Ivorian entrepreneurs because they enter into the creation of new activities. Also, the growing presence of Chinese products gives new opportunities for many young Ivorians to enter the business. Without the mediation of these Ivorians, this new material culture would not have the same impact in Ivory Coast.

\footnotetext{
${ }^{3}$ Interview conducted on October 10, 2015.
} 


\section{When Chinese Presences Create New Figure of Success}

Young unemployed Ivorians benefit from the opportunities offered by the settlement of Chinese in the country. Face to unemployment, Ivorians and other Africans have been engaged on a process of adaptation ${ }^{4}$ (Marfaing Laurence, 2015); that is constantly changing according to the new variables they perceive. Here, these variables are both the Chinese presence as well as that of products from China. Because conditions of access to Chinese products for those who want to be resellers are less constrained than those from Europe. Moreover, in all the markets of the Abidjan capital and the cities of the interior, products "Made in China" are ubiquitous, from clothing to shoes through consumer goods. At the point where the traders who still import from Europe believe that they will not be able to hold very long. As Kakou Eugene ${ }^{5}$ puts it so well: "A few years back, imports of construction materials, tiles, sanitary plumbing and furniture came from European countries. But since 2007, everything comes from China". Listening to "Made in Europe" traders, the arrival of Chinese products has some consequences on Europeans imports. While these traders are shouting at unfair competition, a good part of the youth benefits from the Chinese presence in the fact that they are in direct contact with both the Chinese small traders and the Chinese products.

In Adjamé, one of the commercial districts of Abidjan, when the Chinese began renting stores to turn them into shops in the 2000 years, young Ivorians looking for jobs or having lost their jobs because of the crisis enjoy the opportunity to become street sellers. Others have chosen to install tables in front of Chinese shops to take advantage of the influx of customers attracted by particularly cheap products. Apart from active full-time resellers, there are seasonal or occasional vendors depending on the festivities or events. Thus, the opening of these Chinese businesses has allowed Ivorians to find a job. Other young people were very ingenious in developing a new form of commerce that could be called "trade on the ground". In the working-class neighborhoods of Abidjan, "trade on the land" has rapidly developed as an activity in its own right, thanks to the arrival of Chinese products. Struggling the road with motorists and pedestrians, this activity is dependent on the economic crisis and the socio-economic situation. Not having the means to pay a rent for their activity, young people illegally exercise on public roads.

The paradox of this illegal activity is that it allows up to thousands of people to live. The testimony of Fatou Diallo, a young lady practicing the business by "land" is expressive:

I exercise this activity, because I have no choice, I lost my father and my mother, I manage in the small businesses and I have three brothers to school, for lack of a store that I can not pay elsewhere, I am obliged to use the street to sell. ${ }^{6}$

Many Ivorians trade by "land" because they generally have no alternative; because despite the evictions they suffer from the administrative authorities, this trade continues to flourish in all cities of the country, Ivory Coast. Some of them became real traders, street vendors, and shop owners.

We met Koné Moussa ${ }^{7}$, a reseller of Chinese products in his shop in Treichville. His testimony illustrates the social impact of Chinese products on people's lives. He began as a street vendor of Chinese products, unemployed, he was trying to make a living. He started this business with a capital of 10,000 Francs CFA

\footnotetext{
${ }^{4}$ On the process of adaptation of local populations to the opportunities offered by the Chinese presence, we can read with interest the work of Laurence (2015); Alessandro Triulz (Eds.), Long journeys: Lives and voices of African migrants on the road, Leiden, Brill Aegis African Studies: 135-163.

${ }^{5}$ Interview conducted in Abidjan February 16th, 2015.

6 Interview conducted in Abidjan June 2015.

7 Interview conducted in Abidjan October 2016.
} 
(about $15 €$ ) by buying some products to the Chinese he resold in the Abidjan streets. The shirt bought 1,000 Francs CFA is sold at 1,500 Francs CFA and the shoe purchased 1,000 Francs CFA is sold at 2,000 Francs CFA. As the holiday season approached, he would spend several times a day at the same supplier or at another supplier. Thanks to this rotation, Koné quickly opened a shop. His immediate project is to go sourcing in China to increase his turnover. Like Koné, several Ivorians have seized a business opportunity induced by the presence of Chinese or Chinese products. Moreover, it is thanks to these resellers that Chinese products have become more accessible to the population. In villages, such as remote towns which are poorly served by infrastructure and commerce, they have become indispensable for bringing not only products intended to meet everyday consumption needs, but also to circulate "fashion" cheaply (shoes, clothes, accessories, and cosmetics), thereby influencing the consumption habits of poor local people who, like the middle classes, can also buy new loincloths, new shoes for ceremonies or parties, or simply dress their children for the fall season classes.

These young Ivorian businessmen, excluded from the Ivorian economic system, have become the new figures of success. This reconfiguration relates to the emergence of new entrepreneurs. They are found in both import and resale, as wholesalers or retailers. Some of them pursued dazzling accumulation trajectories, upsetting the existing marketing hierarchies. However, these new entrepreneurs, figures of success "Made in China" seem to have largely participated in injecting into Ivorian society new habits, making ostentatious staging of their wealth consumption practices.

Moreover, in Ivory Coastthere, there is a close relationship between the new figures of success and Chinese products. The affirmation of the social status of the individuals passes by an ostentatious object for which these products are frequently used on the one hand and on the other hand in return, the prestige related to these individuals reflects on these Chinese products, thus participating to increase their symbolic value.

By focusing on Chinese products in Ivory Coast, it is possible to identify a number of economic, social, and political processes that reflect the importance of their impact on Ivorian society. The arrival of "Made in China" in Ivory Coast, however, does not mark a revolution in consumption patterns and the emergence of a new material culture. At the economic and political level, Chinese products have sometimes shaken the system that existed until now. Through the Chinese presences, it seems to take place certain transformations of the logic of predation of the resources of the extraversion towards more indirect forms. In many respects, Chinese products are thus at the heart of a subtle struggle between "elites and non-elites", both for the definition of the cultural codes of modernity (Antoine \& Khan, 2014).

\section{References}

Alden, C. (2007). China in Africa: Partner, competitor or Hegemon? Zed Books.

Antoine, K., \& Khan, M. G. (2014). La révolution des produits chinois en Afrique Consommation de masse et nouvelle culture matérielle. Politique Africaine, 2(134), 111-132.

Aurégan, X. (2016). Géopolitique de la Chine en Côte d'Ivoire. Paris: Riveneuve Éditions.

Belkecem, K. (2011). L'avenir du partenariat Chine-Afrique. Paris: L'Harmattan.

Bokilo, J. (2011). La Chine en Afrique. La Chine en concurrence avec les anciens partenaires de l'Afrique et les pays Brics. Paris: L'Harmattan.

Bredeloup, S., \& Bertoncello, B. (2006). La migration chinoise en Afrique: Accélérateur du développement ou "sanglot de l'homme noir"? Paris: Afrique Contemporaine.

Chaponnière, J. R. (2006). Les échanges entre la Chine et l'Afrique. Stateco.

Chaponnière, J. R. (2009). Un demi-siècle de relations Chine Afrique. Paris: Afrique Contemporaine. 
D’Aboville, R., \& Sun, Q. (2010). Investissement pétroliers chinois en Afrique: Conséquence géopolitique. Paris: L'harmattan. Laurence, M. (2015). Importations de marchandises chinoises et mobilité sous-régionale en Afrique de l'Ouest. Cahiers D'études Africaines, 2(218), 359-380.

Laurence, M., \& Alena, T. (2013). Petits commerçants chinois en Afrique et saturation des marchés ouest-africains. Déconstruction d'une rumeur (Dakar- Accra). Migrations Société.

Laurence, M., \& Thiel, A. (2013). Petits commerçants chinois en Afrique et saturation des marchés ouest-africains. Déconstruction d'une rumeur (Dakar- Accra). Migrations Société, 5(149), 137-158.

Meidan, M. (2007). La Chine à la conquête des marchés énergétiques mondiaux in Hérodote. Paris: La découverte.

Michel, S., \& Beuret, M. (2009). La Chinafrique: Pékin à la conquête du continent noir. Paris: Hachette.

Richer, P. (2008). L'offensive chinoise en Afrique. Paris: Karthala.

Servant, J. C. (2005). La Chine à l'assaut du marché africain. Paris: Monde Diplomatique.

Thompson, D. (2004). Economic growth and soft power: China's Africa strategy. China Brief, 4(24), 7.

Xavier, A. (2013). Représentations, intégrations et organisations: Les enjeux des dynamiques migratoires chinoises à Abidjan (Côte d'Ivoire). Monde Chinois, (33), 55-66.

Xavier, A. (2016). Aide, investissements et migrants-investisseurs: Les interventions chinoises en Côte d'Ivoire. Autrepart, (70), 89-108.

Xavier, A. (2016). Géopolitique de la Chine en Côte d’Ivoire. Paris: Riveneuve Éditions. 


\section{Appendix}

Table 1

Ivory Coast Imports From China

\begin{tabular}{|c|c|c|c|c|c|c|c|c|c|c|}
\hline \multirow[b]{3}{*}{ Value in millions FCFA } & \multicolumn{10}{|c|}{ Ivory coastimports from China (value, weight) } \\
\hline & \multicolumn{2}{|c|}{2012} & \multicolumn{2}{|c|}{2013} & \multicolumn{2}{|c|}{2014} & \multicolumn{2}{|c|}{2015} & \multicolumn{2}{|c|}{2016} \\
\hline & Value & Weight & Value & Weight & Value & Weight & Value & Weight & Value & Weight \\
\hline \multicolumn{11}{|c|}{ Weight in tons } \\
\hline Foodstuffs & 30,326 & 40,846 & 35,031 & 46,636 & 33,703 & 47,442 & 36,257 & 55,960 & 46,593 & 99,760 \\
\hline Dairy products & 3 & 5 & 47 & 6 & 2 & 1 & 24 & 44 & 5 & 8 \\
\hline $\begin{array}{l}\text { Fresh fruits and } \\
\text { vegetables }\end{array}$ & 852 & 1,682 & 1,342 & 2,759 & 1,185 & 2,753 & 1,426 & 2,573 & 2,138 & 2,827 \\
\hline Canned meat & 46 & 49 & 77 & 77 & 58 & 101 & 5 & 1 & 23 & 13 \\
\hline Canned fish & 0 & 0 & 0 & 0 & 0 & 0 & 0 & 0 & 0 & 0 \\
\hline Crabs and shrimps & 0 & 0 & 0 & 0 & 0 & 0 & 0 & 0 & 0 & 0 \\
\hline Fishes & 14,669 & 19,352 & 17,101 & 22,332 & 20,551 & 26,058 & 25,411 & 34,443 & 30,624 & 47,850 \\
\hline Semi-milled rice & 0 & 0 & 3 & 1 & 1 & 1 & 0 & 0 & 6,157 & 30,240 \\
\hline Soft wheat & 0 & 0 & 0 & 0 & 0 & 0 & 0 & 0 & 0 & 0 \\
\hline Other cereals & 16 & 4 & 4 & 2 & 8 & 26 & 169 & 17 & 0 & 0 \\
\hline Sugar & 542 & 1,284 & 864 & 2,259 & 589 & 1,655 & 853 & 3,273 & 1,153 & 4,231 \\
\hline Drinks & 40 & 63 & 0 & 0 & 94 & 193 & 174 & 381 & 10 & 50 \\
\hline Tobacco & 5,835 & 526 & 6,722 & 621 & 3,614 & 355 & 0 & 0 & 0 & 0 \\
\hline Other food products & 8,323 & 17,881 & 8,872 & 18,578 & 7,600 & 16,302 & 8,194 & 15,228 & 6,482 & 14,541 \\
\hline Other consumer goods & 106,860 & 78,546 & 106,932 & 89,573 & 141,856 & 122,162 & 170,283 & 153,844 & 177,225 & 166,063 \\
\hline Clothing & 3,589 & 2,031 & 2,882 & 1,889 & 3,642 & 2,482 & 5,078 & 4,146 & 5,205 & 4,166 \\
\hline Pharmaceutical products & 5,065 & 931 & 4,797 & 515 & 6,545 & 1,196 & 6,437 & 1,146 & 8,188 & 1,138 \\
\hline Bookstore & 540 & 294 & 1,146 & 357 & 434 & 411 & 822 & 337 & 674 & 355 \\
\hline Plastics & 10,455 & 8,180 & 12,091 & 11,859 & 13,854 & 17,052 & 23,599 & 26,57 & 19,078 & 26,073 \\
\hline Rubber & 13,601 & 7,950 & 12,340 & 7,770 & 12,900 & 9,727 & 13,180 & 10,368 & 12,373 & 11,622 \\
\hline Cars & 2,177 & 497 & 1,933 & 515 & 2,162 & 395 & 1,845 & 413 & 2,080 & 404 \\
\hline Personal effects & 190 & 81 & 38 & 36 & 35 & 55 & 0 & 0 & 0 & 0 \\
\hline Other consumer goods & 71,243 & 58,583 & 71,706 & 66,631 & 102,284 & 90,844 & 119,322 & 111,077 & 129,628 & 122,304 \\
\hline Intermediate goods & 86,642 & 200,511 & 123,719 & 543,204 & 134,532 & 454,347 & 203,950 & 459,348 & 210,632 & 657,432 \\
\hline Crude oil & 0 & 0 & 0 & 0 & 0 & 0 & 0 & 0 & 0 & 0 \\
\hline Oil products & 222 & 309 & 360 & 466 & 354 & 449 & 724 & 315 & 640 & 686 \\
\hline Chemical products & 20,355 & 35,095 & 20,463 & 36,719 & 22,718 & 52,203 & 21,651 & 43,085 & 25,995 & 52,207 \\
\hline Cotton & 9,881 & 8,747 & 11,372 & 7,338 & 8,108 & 2,980 & 8,539 & 3,300 & 8,411 & 3,056 \\
\hline Other textile fibers & 8,129 & 7,751 & 8,483 & 8,481 & 9,037 & 9,865 & 10,129 & 10,566 & 10,433 & 11,852 \\
\hline $\begin{array}{l}\text { Iron, cast iron, steel and } \\
\text { articles }\end{array}$ & 25,248 & 40,782 & 46,735 & 102,551 & 55,714 & 135,835 & 115,103 & 233,704 & 122,198 & 335,493 \\
\hline Metal products & 4,002 & 3,495 & 5,622 & 4,165 & 5,281 & 4,438 & 17,878 & 8,304 & 12,195 & 6,536 \\
\hline Ceram. Glass and stone & 10,272 & 89,771 & 11,902 & 95,474 & 13,062 & 108,236 & 13,692 & 112,446 & 14,610 & 143,480 \\
\hline Fertilizer & 777 & 3,700 & 3,697 & 21,439 & 6,499 & 33,988 & 7,118 & 33,314 & 4,189 & 19,285 \\
\hline Clinker & 0 & 0 & 1 & 4 & 0 & 0 & 0 & 0 & 1,777 & 68,483 \\
\hline Other building materials & 516 & 2,981 & 8,475 & 258,181 & 5,039 & 94,965 & 620 & 4,207 & 964 & 5,176 \\
\hline Paper and cardboard & 5,361 & 6,802 & 4,851 & 7,331 & 6,660 & 9,882 & 5,705 & 7,785 & 5,698 & 7,646 \\
\hline Other internal goods. & 1,879 & 1,078 & 1,758 & 1,055 & 2,059 & 1,505 & 2,792 & 2,322 & 3,522 & 3,533 \\
\hline Capital goods & 140,275 & 177,767 & 447,415 & 163,032 & 175,084 & 66,593 & 306,882 & 91,887 & 451,249 & 100,840 \\
\hline Machinery & 39,633 & 16,298 & 58,845 & 24,044 & 62,724 & 24,158 & 85,262 & 29,603 & 100,308 & 33,626 \\
\hline Electrical equipment & 72,041 & 16,634 & 72,372 & 16,007 & 70,720 & 19,597 & 80,318 & 22,852 & 159,702 & 23,958 \\
\hline
\end{tabular}




\begin{tabular}{lllllllllll}
\hline $\begin{array}{l}\text { Road transport } \\
\text { equipment }\end{array}$ & 24,506 & 142,867 & 30,989 & 82,340 & 36,132 & 20,528 & 54,925 & 24,449 & 45,258 & 19,411 \\
$\begin{array}{l}\text { Other Transport } \\
\text { Equipment }\end{array}$ & 8 & 9 & 280,912 & 38,105 & 175 & 75 & 78,941 & 12,879 & 128,999 & 21,217 \\
Precision instrument & 3,858 & 1,756 & 3,871 & 2041 & 4,533 & 1,675 & 6,694 & 1,747 & 16,503 & 2,086 \\
Other equipments. & 228 & 203 & 426 & 496 & 801 & 560 & 742 & 358 & 479 & 541 \\
Total importation & $\mathbf{3 6 4 , 1 0 3}$ & $\mathbf{4 9 7 , 6 7 0}$ & $\mathbf{7 1 3 , 0 9 7}$ & $\mathbf{8 4 2 , 4 4 5}$ & $\mathbf{4 8 5 , 1 7 4}$ & $\mathbf{6 9 0 , 5 4 3}$ & $\mathbf{7 1 7 , 3 7 1}$ & $\mathbf{7 6 1 , 0 3 9}$ & $\mathbf{8 8 5 , 6 9 9}$ & $\mathbf{1 , 0 2 4 , 0 9 6}$ \\
\hline
\end{tabular}

Source: Ministry of Commerce of Craft and SME (Small and medium-sized enterprise) Promotion and Customs Statistics of Côte d'Ivoire.

Table 2

Ivory Coastexports to China

\begin{tabular}{|c|c|c|c|c|c|c|c|c|c|c|}
\hline \multicolumn{11}{|c|}{ Ivory Coast exports to China (in value, weight) } \\
\hline & \multicolumn{2}{|c|}{2012} & \multicolumn{2}{|c|}{2013} & \multicolumn{2}{|c|}{2014} & \multicolumn{2}{|c|}{2015} & \multicolumn{2}{|c|}{2016} \\
\hline Value in millions FCFA & Value & Weight & Value & Weight & Value & Weight & Value & Weight & Value & Weight \\
\hline \multicolumn{11}{|l|}{ Weight in tons } \\
\hline Agriculture, breeding, fishing & 53 & 46 & 14 & 25 & 2 & 2 & 2,585 & 1,902 & 4,426 & 4,595 \\
\hline Cereals & 0 & 0 & 0 & 0 & 0 & 0 & 0 & 0 & 0 & 0 \\
\hline starchy & 0 & 0 & 0 & 0 & 0 & 0 & 0 & 0 & 0 & 0 \\
\hline Breeding and hunting & 0 & 0 & 0 & 0 & 0 & 0 & 0 & 0 & 0 & 0 \\
\hline Peach & 53 & 46 & 14 & 25 & 2 & 2 & 2,585 & 1,902 & 4,426 & 4,595 \\
\hline Other fruits & 0 & 0 & 0 & 0 & 0 & 0 & 0 & 0 & 0 & 0 \\
\hline Industrial and export agriculture & 48,600 & 44,319 & 47,635 & 49,661 & 40,773 & 43,653 & 44,229 & 55,549 & 29,487 & 35,297 \\
\hline Green coffee & 0 & 0 & 0 & 0 & 0 & 0 & 0 & 0 & 0 & 0 \\
\hline Cocoa beans & 5,410 & 4,805 & 6,883 & 6,052 & 12,106 & 9,136 & 4,470 & 2,903 & 8,610 & 5,036 \\
\hline Cola & 0 & 0 & 1 & 18 & 0 & 0 & 0 & 0 & 0 & 0 \\
\hline Cashew nut & 635 & 1,561 & 295 & 796 & 538 & 1,258 & 374 & 692 & 227 & 310 \\
\hline Fresh pineapple & 0 & 0 & 0 & 0 & 0 & 0 & 0 & 0 & 0 & 0 \\
\hline Banana & 0 & 0 & 0 & 0 & 0 & 0 & 0 & 0 & 0 & 0 \\
\hline Mass cotton & 33,367 & 32,267 & 33,601 & 36,876 & 13,627 & 15,011 & 12,652 & 16,464 & 1,980 & 2,394 \\
\hline Oleaginous & 3 & 29 & 7 & 31 & 60 & 175 & 29 & 98 & 41 & 137 \\
\hline Oilseed seeds & 0 & 0 & 3 & 63 & 130 & 432 & 158 & 310 & 8 & 25 \\
\hline Rubber & 9,184 & 5,657 & 6,844 & 5,825 & 14,312 & 17,640 & 26,547 & 35,082 & 18,622 & 27,395 \\
\hline Sugar & 0 & 0 & 0 & 0 & 0 & 0 & 0 & 0 & 0 & 0 \\
\hline Tobacco & 0 & 0 & 0 & 0 & 0 & 0 & 0 & 0 & 0 & 0 \\
\hline Other & 0 & 0 & 0 & 0 & 0 & 0 & 0 & 0 & 0 & 0 \\
\hline Wood & 5,110 & 51,969 & 11,452 & 150,005 & 13,926 & 81,399 & 995 & 6,089 & 638 & 3,372 \\
\hline Log wood & 3,829 & 45,212 & 10,181 & 143,477 & 130 & 1,519 & 0 & 0 & 1 & 16 \\
\hline Transformed wood & 1,280 & 6,757 & 1,271 & 6,528 & 13,795 & 79,881 & 995 & 6,089 & 637 & 3,356 \\
\hline Preserves and food preparation & 616 & 413 & 423 & 1,054 & 742 & 1,396 & 1,301 & 574 & 1,811 & 836 \\
\hline Processed cocoa & 616 & 413 & 309 & 187 & 725 & 520 & 1,300 & 574 & 1,811 & 836 \\
\hline Processed coffee & 0 & 0 & 0 & 0 & 0 & 0 & 0 & 0 & 0 & 0 \\
\hline Canned tuna & 0 & 0 & 0 & 0 & 0 & 0 & 0 & 0 & 0 & 0 \\
\hline Canned pineapple & 0 & 0 & 0 & 0 & 0 & 0 & 0 & 0 & 0 & 0 \\
\hline Pineapple juice & 0 & 0 & 0 & 0 & 0 & 0 & 0 & 0 & 0 & 0 \\
\hline Smoked fish & 0 & 0 & 0 & 0 & 0 & 0 & 0 & 0 & 0 & 0 \\
\hline sweet things & 0 & 0 & 0 & 0 & 0 & 0 & 0 & 0 & 0 & 0 \\
\hline Palm oil & 0 & 0 & 0 & 0 & 0 & 0 & 0 & 0 & 0 & 0 \\
\hline Palm kernel oil & 0 & 0 & 0 & 0 & 0 & 0 & 0 & 0 & 0 & 0 \\
\hline Other preserves and preparations & 0 & 0 & 113 & 867 & 17 & 876 & 0 & 0 & 0 & 0 \\
\hline
\end{tabular}




\begin{tabular}{|c|c|c|c|c|c|c|c|c|c|c|}
\hline Others products & 1,137 & 10,424 & 15,792 & 193,405 & 15,393 & 281,127 & 7,135 & 145,073 & 6,022 & 298,033 \\
\hline \multicolumn{11}{|l|}{ Whose : } \\
\hline Fertilizer & 0 & 0 & 0 & 0 & 0 & 0 & 0 & 0 & 0 & 0 \\
\hline Essential oils & 0 & 0 & 0 & 0 & 0 & 0 & 0 & 0 & 0 & 0 \\
\hline Chemical Miscellaneous & 0 & 0 & 0 & 0 & 0 & 0 & 0 & 0 & 0 & 0 \\
\hline Plastics & 25 & 247 & 14 & 138 & 30 & 321 & 6 & 142 & 3 & 149 \\
\hline Oil products & 0 & 0 & 81 & 209 & 14 & 26 & 0 & 0 & 0 & 0 \\
\hline Cement & 0 & 0 & 0 & 0 & 0 & 0 & 0 & 0 & 0 & 0 \\
\hline Paper and cardboard & 0 & 0 & 0 & 0 & 16 & 85 & 0 & 0 & 0 & 0 \\
\hline Various & 1,112 & 10,177 & 15,697 & 193,058 & 15,334 & 280,695 & 7,129 & 144,931 & 6,019 & 297,884 \\
\hline Total export & 55,515 & 107,170 & 75,316 & 394,151 & 70,836 & 407,577 & 56,245 & 209,187 & 42,383 & 342,133 \\
\hline
\end{tabular}

Source: Ministry of Commerce of Craft and SME Promotion and Customs Statistics of Côte d'Ivoire. 